\title{
Admission Plasma Glucose and Maternal Prognostic Factors in Preeclampsia
}

\author{
Ozgur Kirbas, Ebru Hacer Biberoglu', Nuri Danisman ${ }^{1}$ \\ Department of Cardiology, Yuksek intisas University, 'Deparment of Perinatology, Zekai Tahir Burak Women's Health Care, Education and Research Hospital, Ankara, \\ Turkey \\ ORCID: \\ Ozgur Kirbas: https://orcid.org/0000-0003-1292-2996 \\ Ebru Hacer Biberoglu: https://orcid.org/0000-0003-0801-7514 \\ Nuri Danisman: https://orcid.org/0000-0001-7751-4710
}

\section{Abstract}

Aims: We aimed to investigate if admission plasma glucose (PG) level was a significant and independent risk factor for the patients' length of stay at the intensive care unit (ICU), as the primary outcome parameter, and also for the maternal and fetal complications, as the secondary outcome parameters, among a group of nondiabetic pregnant women with severe preeclampsia. Materials and Methods: In this prospective case-control study including 63 pregnant women, admission PG, glycosylated hemoglobin, neutrophil-lymphocyte ratio, platelet count, liver enzymes, and other laboratory parameters and clinical characteristics including length of stay at the hospital, maternal, and fetal complications were investigated. Results: Admission PG levels were found to be significantly elevated in preeclamptic women with poor outcome. Furthermore, platelet count, fibrinogen, alanine aminotransferase, and aspartate aminotransferase values were significantly associated with the length of stay at ICU. Conclusion: We claimed that hyperglycemia was an acute reaction, reflecting the severity of preeclampsia and PG levels to be added to the routine high-risk pregnancy panel on initial presentation to the hospital.

Keywords: Eclampsia, fibrinogen, glycosylated hemoglobin, hellp syndrome, intensive care unit, neutrophil, platelet

\section{INTRODUCTION}

Prior studies have suggested that stress-induced metabolic response to homeostatic threats leads to hyperglycemia as a consequence of enhanced glucose production, diminished insulin synthesis, and insulin resistance in peripheral tissues. ${ }^{[1]}$ While sustained hyperglycemia may induce substrate mobilization, leading to abnormalities in defence mechanisms and organ functions, acute hyperglycemia, contrarily, may be beneficial to the stressed organism. ${ }^{[2]}$ Although some have claimed that increased glucose on admission is a predictor of adverse outcomes such as mortality, ${ }^{[3]}$ morbidity, length of hospital stay and infections in emergencies like myocardial infarction, ${ }^{[4-6]}$ stroke, ${ }^{[7,8]}$ and in other acute conditions including trauma, ${ }^{[9]}$ others have suggested that lower glucose level on admission may be associated with worse outcomes ${ }^{[10,11]}$ after an acute event, such as myocardial infarction.

Submission: 18-Oct-18 Revision: 26-Oct-18 Accepted: 02-Aug-19
Published Online: 25-Nov-19
Access this article online
Quick Response Code:
Website:
http:/www.ijcva.com

Maternal hyperglycemia during pregnancy has also been correlated with increased risk of maternal complications, including pregnancy-induced hypertension and preeclampsia, and fetal complications such as intrauterine fetal demise, congenital anomalies, neonatal hypoglycemia, and hyperbilirubinemia. ${ }^{[12]}$ Despite clinical data demonstrating the impact of admission glucose on the outcome in different clinical situations, definitions of hyperglycemia are inconsistent, ranging from 6 to $8 \mathrm{mmol} / \mathrm{L}(110-145 \mathrm{mg} / \mathrm{dL})$ for nondiabetic patients and up to $11 \mathrm{mmol} / \mathrm{L}(200 \mathrm{mg} / \mathrm{dL})$ for diabetic patients. ${ }^{[5]}$

The American Diabetes Association (ADA) has defined gestational diabetes mellitus (GDM) as glucose intolerance

Address for correspondence: Dr. Ozgur Kirbas, Department of Cardiology, Yuksek İhtisas University, Ankara, Turkey. E-mail: ozgurkirbas@yahoo.com

This is an open access journal, and articles are distributed under the terms of the Creative Commons Attribution-NonCommercial-ShareAlike 4.0 License, which allows others to remix, tweak, and build upon the work non-commercially, as long as appropriate credit is given and the new creations are licensed under the identical terms.

For reprints contact: reprints@medknow.com

How to cite this article: Kirbas O, Biberoglu EH, Danisman N. Admission plasma glucose and maternal prognostic factors in preeclampsia. Int $\mathrm{J}$ Cardiovasc Acad 2019;5:121-8. 
with onset during pregnancy. ${ }^{[13]}$ The hyperglycemia and adverse pregnancy outcome study ${ }^{[14]}$ and the task force of the International Association of Diabetes and Pregnancy Study Groups, recommend that the diagnosis of GDM be made, when one or more of the following criteria are met: fasting plasma glucose (PG) 5.1-6.9 mmol/1 (92-125 mg/dl); 1-h $\mathrm{PG} \geq 10.0 \mathrm{mmol} / 1(180 \mathrm{mg} / \mathrm{dl})$ following a $75 \mathrm{~g}$ oral glucose load; 2-h PG 8.5-11.0 mmol/1 (153-199 mg/dl) following a $75 \mathrm{~g}$ oral glucose load, ${ }^{[15]}$ instead of current ADA recommendations ${ }^{[16]}$ of at least 2 of the following tresholds are met or exceeded: fasting $95 \mathrm{mg} / \mathrm{dL}, 1-\mathrm{h} 180 \mathrm{mg} / \mathrm{dL}$, or 2 h $155 \mathrm{mg} / \mathrm{dL}$. Glycosylated hemoglobin $(\mathrm{HbA} 1 \mathrm{c})$ reflects antecedent glycometabolic state and is minimally affected by stress during acute emergencies; ${ }^{[13]}$ the relationship between $\mathrm{HbA} 1 \mathrm{c}$ and the short-term prognosis in acute obstetric complications has not been well defined.

Recently, neutrophil count and neutrophil-lymphocyte ratio (NLR) are being investigated as potential prognostic biomarkers in critically ill patients. Data are lacking in preeclampsia and in other pregnancy complications.

Our primary aim in this study, for the first time in the literature, was to investigate if admission PG level was a significant and independent risk factor for the patients' length of stay at the intensive care unit (ICU), as the primary outcome parameter, and also for the maternal and fetal complications, as the secondary outcome parameters, among a group of pregnant women with severe preeclampsia. Therefore, we also studied HbA1c, NLR, platelet count, liver enzymes and other laboratory parameters, clinical characteristics, like length of stay at the hospital, overall and after being discharged from the ICU, cesarean section rate, and birth weight.

\section{Materials and Methods}

Sixty-three nulliparous pregnant women with severe preeclampsia were recruited consecutively for this prospective case-control study between February 2014 and August 2014 at the high-risk pregnancy unit at Zekai Tahir Burak Women's Health Care, Education And Research Hospital, Ankara, Turkey. The study was approved by the institutional review board of the hospital. The universal principles of Declaration of Helsinki were applied.

Diagnosis of preeclampsia is based on systolic blood pressure $\geq 140 \mathrm{mmHg}$ or diastolic blood pressure $\geq 90 \mathrm{mmHg}$ measured while resting for two $4-h$ intervals after the $20^{\text {th }}$ gestational week, as well as proteinuria of $300 \mathrm{mg} / \mathrm{dL}$ detected in a 24-h urine sample, or in the absence of proteinuria, hypertension together with evidence of systemic disease including thrombocytopenia, increased levels of liver transaminases, renal failure, pulmonary edema, and visual or cerebral disturbances. ${ }^{[17]}$ The diagnosis of severe preeclampsia was based on the presence of any of the following criteria: systolic blood pressure $\geq 160 \mathrm{mmHg}$ or diastolic blood pressure $\geq 110 \mathrm{mmHg}$ on two separate measurements performed at 6-h intervals at the least, increased serum creatinine $(>1.1 \mathrm{mg} / \mathrm{dL})$, headache, visual impairment, epigastric pain or pain in the right upper quadrant, elevated hepatic enzymes (to twice normal concentration), thrombocytopenia (platelet $<100,000 / \mathrm{mm}^{3}$ ), or pulmonary edema. ${ }^{[18]}$

Women with preexisting or a history of medical conditions, including chronic hypertension, prediabetes, diabetes mellitus - fasting PG $\geq 7.0 \mathrm{mmol} / 1$ (126 mg/dl), $2-\mathrm{h}$ $\mathrm{PG} \geq 11.1 \mathrm{mmol} / 1$ (200 mg/dl) following a $75 \mathrm{~g}$ oral glucose load, random $\mathrm{PG} \geq 11.1 \mathrm{mmol} / 1$ (200 mg/dl), HbAlc $>5.7 \%$ $(5.7 \%-6.4 \% \text { prediabetes, } \geq 6.5 \% \text { diabetes })^{[16]}$ or other cardiovascular, endocrinological, urogenital, gastrointestinal, autoimmune or oncological disease thrombophilia, multiple gestation or trophoblastic disease, women who use medications that may interfere with blood glucose, such as glucocorticoids, who has pregestatioanal obesity (body mass index [BMI], BMI >30), and smokers, were excluded.

The clinical data (age, BMI, body temperature, systolic and diastolic blood pressure, gestational age, length of hospital, ICU, post-ICU stay, birthweight, maternal, and fetal complications) and the blood samples were collected prospectively, but laboratory workup and data evaluation were achieved retrospectively, without any intervention. During hospital admission, blood samples were obtained from the antecubital vein early in the morning, following $8 \mathrm{~h}$ of fasting, and PG, HbA1c, complete blood count, NLR, alanine aminotransferase (ALT), aspartate aminotransferase (AST), lactic acid dehydrogenase (LDH), international normalized ratio (INR), and fibrinogen assessments were carried out at the central laboratories of Zekai Tahir Burak Women's Hospital, Ankara. Subsequently, all of the severe preeclamptic women followed up with an institutional standard protocol which was compatible with the one defined previously. ${ }^{[19]}$

The statistical analysis was conducted with the Statistical Package for the Social Sciences v 11.5 for Windows (Chicago, IL, USA). Data were summarized as mean \pm standard deviation (SD) and median (range). Student's $t$-test or Mann-Whitney U-test was used for group comparisons depending on distributions. Correlations were assessed using Pearson or Spearman correlation analysis. A two-sided $P<0.05$ was considered to be statistically significant. Continuous variables were examined using oneway ANOVA or Kruskal-Wallis tests if data were not normally distributed. The statistical test and correlation coefficient were chosen according to whether the data distribution was normal or not. Multivariate regression analysis and backward stepwise elimination were used for calculating variable dependent length of ICU stay. We utilized the Kolmogorov-Smirnov test to show that our sample came from a normally distributed population.

\section{RESULTS}

In the study, 63 pregnant women with severe preeclampsia were hospitalized and treated at the ICU. As shown in Table 1, they were all young (27.41 years), overweight $\left(28.74 \mathrm{~kg} / \mathrm{m}^{2}\right)$ by World Health Organization criteria, stage 2 hypertensive $(160.96 / 102.20 \mathrm{mmHg})$ by the American Heart 


\begin{tabular}{|c|c|}
\hline Parameter & Results \\
\hline Age (year), mean $\pm \mathrm{SD}$ & $27.41 \pm 4.14$ \\
\hline $\mathrm{BMI}\left(\mathrm{kg} / \mathrm{m}^{2}\right)$, mean $\pm \mathrm{SD}$ & $28.74 \pm 2.00$ \\
\hline Systolic BP (mmHg), mean \pm SD & $160.96 \pm 12.78$ \\
\hline Diastolic BP (mmHg), mean \pm SD & $102.20 \pm 11.10$ \\
\hline Gestational age (weeks), mean \pm SD & $31.60 \pm 3.97$ \\
\hline Admission fasting glucose $(\mathrm{mg} / \mathrm{dL})$, mean $\pm \mathrm{SD}$ & $100.88 \pm 30.52$ \\
\hline Discharge fasting glucose (mg/dL), mean $\pm \mathrm{SD}$ & $87.61 \pm 15.95$ \\
\hline Fasting glucose difference* $(\mathrm{mg} / \mathrm{dL})$, mean $\pm \mathrm{SD}$ & $13.26 \pm 31.72$ \\
\hline $\mathrm{HbA} 1 \mathrm{c}, \operatorname{mean} \pm \mathrm{SD}$ & $4.71 \pm 0.37$ \\
\hline $\mathrm{Hb}(\%)$, mean $\pm \mathrm{SD}$ & $13.06 \pm 1.69$ \\
\hline Hematocrit $(\%)$, mean \pm SD & $38.67 \pm 4.66$ \\
\hline Platelet $(\mu \mathrm{L})$, mean $\pm \mathrm{SD}$ & $17,5873.01 \pm 78,084.42$ \\
\hline $\mathrm{N}(\mu \mathrm{L})$, mean $\pm \mathrm{SD}$ & $9.75 \pm 3.86$ \\
\hline $\mathrm{L}(\mu \mathrm{L})$, mean $\pm \mathrm{SD}$ & $2.22 \pm 0.81$ \\
\hline $\mathrm{N} / \mathrm{L}$ ratio, mean $\pm \mathrm{SD}$ & $5.25 \pm 4.32$ \\
\hline $\mathrm{INR}$, mean $\pm \mathrm{SD}$ & $0.89 \pm 0.08$ \\
\hline Fibrinogen $(\mathrm{mg} / \mathrm{dL})$, mean $\pm \mathrm{SD}$ & $393.58 \pm 134.97$ \\
\hline Newborn weight (g), mean \pm SD & $1600.63 \pm 760.07$ \\
\hline Hospital stay (day), mean \pm SD & $5.63 \pm 2.73$ \\
\hline $\mathrm{ICU}$ stay (day), mean $\pm \mathrm{SD}$ & $2.16 \pm 1.57$ \\
\hline Post-ICU stay (day), mean \pm SD & $3.47 \pm 2.13$ \\
\hline LDH (U/L), median (range) & $522.00(178.00-2913.00)$ \\
\hline ALT (U/L), median (range) & $23.00(4.00-1822.00)$ \\
\hline $\operatorname{AST}(\mathrm{U} / \mathrm{L})$, median (range) & $29.00(12.00-2166.00)$ \\
\hline \multicolumn{2}{|c|}{$\begin{array}{l}\text { *Significant (two-tailed) } P \text { 0.002. ICU: Intensive care unit, BMI: Body } \\
\text { mass index, HbA1c: Glycosylated hemoglobin, SD: Standard deviation, } \\
\text { LDH: Lactic acid dehydrogenase, ALT: Alanine aminotransferase, } \\
\text { AST: Aspartate aminotransferase, INR: International normalized ratio, } \\
\text { N/L ratio: Neutrophil/lymphocyte ratio, BP: Blood pressure }\end{array}$} \\
\hline
\end{tabular}

Association criteria, all in the third trimester (31.6 weeks). Mean birth weight was $1600.63 \pm 760.07 \mathrm{~g}$. Forty-eight out of 63 fetuses $(76.2 \%)$ were defined to have intrauterine growth retardation. Although there was no maternal mortality, perinatal mortaliy rate was $28.6 \%$ (18 of 45 ). While the patients stayed at the hospital on average for 5.6 days, 2.6 days of it was at ICU.

Laboratory characteristics (mean $\pm \mathrm{SD}$ ) of the cases by glucose status are presented in Table 2.

Table 3 summarizes the clinical and laboratory characteristics by length of stay $\leq 2$ versus $>2$ days at ICU. As shown in Table 3, the longer the duration of patients' ICU stay, the higher their fasting PG, neutrophil count, NLR, LDH, ALT, and AST values and the lower the platelet count and fibrinogen levels were, among pregnant women with severe preeclampsia.

Hyperglycemia was found to be correlated with the development of hemolysis, elevated liver enzymes, low platelet count syndrome (HELLP) syndrome $(P=0.019)$, eclampsia $(P=0.017)$, and disseminated intravascular coagulation (DIC) $(P=0.017)$, as demonstrated in Table 4.

Contrarily, only women with HELLP syndrome stayed significantly longer $(P=0.001)$ at the ICU $(>2$ days $)$ [Table 5].
Table 2: Laboratory characteristics among pregnant women with preeclampsia by glucose status

\begin{tabular}{|c|c|c|}
\hline Parameter & $P G(m g / d L)$ & Results \\
\hline \multirow[t]{2}{*}{$\mathrm{HbAlc}$, mean $\pm \mathrm{SD}$} & $\leq 92$ & $4.70 \pm 0.37$ \\
\hline & $>92$ & $4.71 \pm 0.38$ \\
\hline \multirow[t]{2}{*}{$\mathrm{Hb}(\%)$, mean $\pm \mathrm{SD}$} & $\leq 92$ & $12.87 \pm 1.40$ \\
\hline & $>92$ & $13.30 \pm 1.97$ \\
\hline \multirow[t]{2}{*}{ Hematocrit (\%), mean \pm SD } & $\leq 92$ & $38.45 \pm 4.10$ \\
\hline & $>92$ & $38.94 \pm 5.31$ \\
\hline \multirow[t]{2}{*}{ Platelet $(\mu \mathrm{L})$, mean \pm SD } & $\leq 92$ & $19,2558.82 \pm 68,948.02$ \\
\hline & $>92$ & $15,6310.34 \pm 84,638.77$ \\
\hline \multirow[t]{2}{*}{$\mathrm{N}(\mu \mathrm{L}), \operatorname{mean} \pm \mathrm{SD}$} & $\leq 92$ & $8.85 \pm 3.16$ \\
\hline & $>92$ & $10.81 \pm 4.37$ \\
\hline \multirow[t]{2}{*}{$\mathrm{L}(\mu \mathrm{L})$, mean $\pm \mathrm{SD}$} & $\leq 92$ & $2.33 \pm 0.83$ \\
\hline & $>92$ & $2.10 \pm 0.77$ \\
\hline \multirow[t]{2}{*}{$\mathrm{N} / \mathrm{L}$ ratio, mean $\pm \mathrm{SD}$} & $\leq 92$ & $4.55 \pm 4.67$ \\
\hline & $>92$ & $6.07 \pm 3.78$ \\
\hline \multirow[t]{2}{*}{$\mathrm{INR}$, mean $\pm \mathrm{SD}$} & $\leq 92$ & $0.89 \pm 0.06$ \\
\hline & $>92$ & $0.90 \pm 0.09$ \\
\hline \multirow{2}{*}{$\begin{array}{l}\text { Fibrinogen }(\mathrm{mg} / \mathrm{dL}) \\
\text { mean } \pm \mathrm{SD}\end{array}$} & $\leq 92$ & $403.76 \pm 111.69$ \\
\hline & $>92$ & $381.65 \pm 159.26$ \\
\hline \multirow{2}{*}{$\begin{array}{l}\text { Intensive care (day), } \\
\text { mean } \pm \text { SD }\end{array}$} & $\leq 92$ & $2.00 \pm 1.27$ \\
\hline & $>92$ & $2.34 \pm 1.87$ \\
\hline \multirow[t]{2}{*}{ Hospital (day), mean \pm SD } & $\leq 92$ & $4.70 \pm 1.85$ \\
\hline & $>92$ & $6.72 \pm 3.19$ \\
\hline \multirow{2}{*}{$\begin{array}{l}\text { Newborn weight (g), } \\
\text { mean } \pm \text { SD }\end{array}$} & $\leq 92$ & $1658.82 \pm 634.15$ \\
\hline & $>92$ & $1532.41 \pm 892.37$ \\
\hline \multirow[t]{2}{*}{ LDH (U/L), median (range) } & $\leq 92$ & $535.00(178-2799)$ \\
\hline & $>92$ & $492.00(206-2913)$ \\
\hline \multirow[t]{2}{*}{ ALT (U/L), median (range) } & $\leq 92$ & $20.50(6-1822)$ \\
\hline & $>92$ & $60.00(4-1502)$ \\
\hline \multirow[t]{2}{*}{ AST (U/L), median (range) } & $\leq 92$ & $26.50(12-2166)$ \\
\hline & $>92$ & $40.00(12-849)$ \\
\hline
\end{tabular}

HbA1c: Glycosylated hemoglobin, SD: Standard deviation,

$\mathrm{N} / \mathrm{L}$ ratio: Neutrophil/lymphocyte ratio, INR: International normalized ratio, LDH: Lactic acid dehydrogenase, ALT: Alanine aminotransferase, AST: Aspartate aminotransferase, PG: Plasma glucose

Length of ICU stay and birth weight were studied with regard to admission $\mathrm{PG}$, and only a significant correlation was found between birth weight below $1800 \mathrm{~g}$ and hyperglycemia $(P=0.035)$ [Table 6].

Tables 7 and 8 presented data regarding perinatal complications and Table 9 regarding birth weight status, when PG and HbA1c levels were considered as reference points. While hyperglycemia was found to have a significant correlation with the development of HELLP syndrome $(P=0.007)$, eclampsia $(P=0.027)$, and renal failure $(P=0.000), \mathrm{HbA} 1 \mathrm{c}$ was not correlated with any one of the complications. Contrarily, the mean $\mathrm{HbA} 1 \mathrm{c}$ values were lower in women who delivered fetuses weighing below $1800 \mathrm{~g}$ when compared with the ones $\geq 1800 \mathrm{~g}(P=0.003)$.

$\mathrm{HbA} 1 \mathrm{c}$ had a positive correlation with platelet count and birth weight and a negative correlation with $\mathrm{Hb}$ and hematocrit levels [Table 10]. NLR was positively correlated with PG levels, and length of ICU and hospital stay [Table 11]. 
Mean PG, neutrophil, NLR, LDH, AST, and ALT values determined the length of patients' stay at ICU [Table 12].

Finally, in Table 13, platelet count was negatively correlated with $\mathrm{PG}, \mathrm{Hb}$, hematocrit, and diastolic blood pressure and was positively correlated with $\mathrm{HbA} 1 \mathrm{c}$. Moreover, neutrophil count and INR were inversely correlated with gestational week $(r=-0.309, P=0.014)$ and fibrinogen levels $(r=-0.504, P=0.001)$, respectively.

\begin{tabular}{|c|c|c|}
\hline Parameter & ICU day & Results \\
\hline \multirow{2}{*}{$\begin{array}{l}\text { Admission fasting glucose } \\
(\mathrm{mg} / \mathrm{dL}), \text { mean } \pm \mathrm{SD}\end{array}$} & $\leq 2$ & $96.57 \pm 22.49$ \\
\hline & $>2$ & $113.56 \pm 45.50$ \\
\hline \multirow[t]{2}{*}{$\mathrm{HbA1c}$, mean $\pm \mathrm{SD}$} & $\leq 2$ & $4.75 \pm 0.35$ \\
\hline & $>2$ & $4.58 \pm 0.43$ \\
\hline \multirow[t]{2}{*}{$\mathrm{Hb}(\%)$, mean $\pm \mathrm{SD}$} & $\leq 2$ & $12.87 \pm 1.61$ \\
\hline & $>2$ & $13.63 \pm 1.83$ \\
\hline \multirow[t]{2}{*}{ Hematocrit $(\%)$, mean \pm SD } & $\leq 2$ & $38.28 \pm 4.42$ \\
\hline & $>2$ & $39.83 \pm 5.30$ \\
\hline \multirow[t]{2}{*}{ Platelet $(\mu \mathrm{L})$, mean $\pm \mathrm{SD}$} & $\leq 2$ & $19,4319.14 \pm 72,847.69$ \\
\hline & $>2$ & $12,1687.50 \pm 68,771.81$ \\
\hline \multirow[t]{2}{*}{$\mathrm{N}(\mu \mathrm{L})$, mean $\pm \mathrm{SD}$} & $\leq 2$ & $9.24 \pm 3.67$ \\
\hline & $>2$ & $11.25 \pm 4.14$ \\
\hline \multirow[t]{2}{*}{$\mathrm{L}(\mu \mathrm{L})$, mean $\pm \mathrm{SD}$} & $\leq 2$ & $2.21 \pm 0.81$ \\
\hline & $>2$ & $2.27 \pm 0.84$ \\
\hline \multirow[t]{2}{*}{$\mathrm{N} / \mathrm{L}$ ratio, mean $\pm \mathrm{SD}$} & $\leq 2$ & $4.67 \pm 2.52$ \\
\hline & $>2$ & $6.95 \pm 7.32$ \\
\hline \multirow[t]{2}{*}{$\mathrm{INR}$, mean $\pm \mathrm{SD}$} & $\leq 2$ & $0.89 \pm 0.07$ \\
\hline & $>2$ & $0.91 \pm 0.09$ \\
\hline \multirow{2}{*}{$\begin{array}{l}\text { Fibrinogen }(\mathrm{mg} / \mathrm{dL}) \\
\text { mean } \pm \mathrm{SD}\end{array}$} & $\leq 2$ & $415.55 \pm 111.80$ \\
\hline & $>2$ & $329.06 \pm 176.11$ \\
\hline \multirow[t]{2}{*}{ LDH (U/L), median (range) } & $\leq 2$ & $479.00(178-2913)$ \\
\hline & $>2$ & $740.50(359-2799)$ \\
\hline \multirow[t]{2}{*}{$\operatorname{ALT}(\mathrm{U} / \mathrm{L})$, median (range) } & $\leq 2$ & $19.00(6-1502)$ \\
\hline & $>2$ & $71.00(4-1822)$ \\
\hline \multirow[t]{2}{*}{$\operatorname{AST}(\mathrm{U} / \mathrm{L})$, median (range) } & $\leq 2$ & $25.00(12-849)$ \\
\hline & $>2$ & $61.50(12-2166)$ \\
\hline
\end{tabular}

ICU: Intensive care unit, HbA1c: Glycosylated hemoglobin, SD: Standard deviation, N/L ratio: Neutrophil/lymphocyte ratio, INR: International normalized ratio, LDH: Lactic acid dehydrogenase, ALT: Alanine aminotransferase, AST: Aspartate aminotransferase
A multivariate analysis showed that admission PG $(P=0.001)$, also platelet count $(P=0.045)$, fibrinogen $(P=0.001)$, AST $(P=0.041)$, and ALT $(P=0.035)$ were still significantly associated with the length of stay at ICU, even after all associated risk factors were entered into the logistic regression model.

On multivariate analysis, admission PG over 92 $\mathrm{mg} / \mathrm{dL}$ remained a significant predictor of HELLP syndrome (odds ratio $[\mathrm{OR}]=3.7995 \%$ confidence interval $[\mathrm{CI}]$ : $1.20-11.92)$, of eclampsia $(\mathrm{OR}=1.2095 \% \mathrm{CI}: 1.023-1.42)$, of DIC (OR $=1.2095 \% \mathrm{CI}: 1.02-1.42)$, and of birth weight below $1800 \mathrm{~g}(\mathrm{OR}=3.143$ 95\% CI: 1.063-9.293). Among newborns with birth weight $\geq 1800 \mathrm{~g}$, OR of maternal admission PG being measured more than $92 \mathrm{mg} / \mathrm{dL}$ was decreased $(\mathrm{OR}=0.659$ 95\% CI: 0.445-0.977). Contrarily, among newborns with birth weight below $1800 \mathrm{~g}$, relative risk of mothers having admission PG above $92 \mathrm{mg} / \mathrm{dL}$ was higher (OR $=2.071$ 95\% CI: 1.001-9.293). The relative risk of staying at ICU more than 2 days was significantly increased only in the presence of HELLP syndrome $(\mathrm{OR}=7.0395 \%$ CI: 2.02-24.46).

\section{Discussion}

Preeclampsia is considered primarily to be a vascular disorder, associated with an ischemic placenta, endothelial cell dysfunction, ${ }^{[20]}$ intravascular inflammation, ${ }^{[21]}$ and activation of the hemostatic system. ${ }^{[22]}$ The clinical manifestations of preeclampsia result from the involvement of multiple organs, including the kidneys, liver, brain, heart, lung, and pancreas. ${ }^{[23]}$

Diabetes mellitus ${ }^{[24]}$ and even lesser degrees of glucose intolerance have also been shown to be associated with adverse maternal and perinatal outcomes. ${ }^{[25,26]}$ Even in the absence of prediabetes and diabetes, maternal hyperglycemia and insulin resistance as a stress-induced metabolic response during pregnancy have been shown to be correlated with increased risk of maternal and fetal complications. ${ }^{[12]}$ This contradicts the evidence which supports the opinion that stress hyperglycemia may be protective against homeostatic threats, allowing the host to survive during periods of severe stress. ${ }^{[26]}$ Indeed, it has been demonstrated that critically ill adults with stress

\begin{tabular}{|c|c|c|c|c|c|c|c|c|c|c|c|c|c|c|}
\hline \multirow[t]{2}{*}{ PG } & \multicolumn{2}{|c|}{ HELLP } & \multicolumn{2}{|c|}{ Eclampsia } & \multicolumn{2}{|c|}{ Renal failure } & \multicolumn{2}{|c|}{ Ablatio placenta } & \multicolumn{2}{|c|}{ DIC } & \multicolumn{2}{|c|}{ IUGR } & \multicolumn{2}{|c|}{ Perinatal mortality } \\
\hline & + & - & + & - & + & - & + & - & + & - & + & - & + & - \\
\hline \multicolumn{15}{|l|}{$\leq 92$} \\
\hline$n$ & 6 & 28 & 0 & 34 & 0 & 34 & 1 & 33 & 0 & 34 & 26 & 8 & 7 & 27 \\
\hline Percentage & 31.6 & 63.6 & 0.0 & 58.6 & 0.0 & 55.7 & 25.0 & 55.9 & 0 & 58.6 & 54.2 & 53.3 & 38.9 & 60.0 \\
\hline \multicolumn{15}{|l|}{$>92$} \\
\hline$n$ & 13 & 16 & 5 & 24 & 2 & 27 & 3 & 26 & 5 & 24 & 22 & 7 & 11 & 18 \\
\hline Percentage & 68.4 & 36.4 & 100 & 41.4 & 100 & 44.3 & 75.0 & 44.1 & 10041.4 & & 45.8 & 46.7 & 61.1 & 40.0 \\
\hline Total $^{\#}$ & 19 & 44 & 5 & 58 & 2 & 61 & 4 & 59 & 5 & 58 & 48 & 15 & 18 & 45 \\
\hline$P$ & \multicolumn{2}{|c|}{$0.019 *$} & \multicolumn{2}{|c|}{$0.017 * *$} & \multicolumn{2}{|c|}{$0.20 * *$} & \multicolumn{2}{|c|}{$0.32 * *$} & \multicolumn{2}{|c|}{$0.017 * *$} & \multicolumn{2}{|c|}{$0.955^{*}$} & \multicolumn{2}{|c|}{$0.12 *$} \\
\hline
\end{tabular}

*Pearson $\chi^{2}, * *$ Fisher's exact test. DIC: Disseminated intravascular coagulation, HELLP: Hemolysis, elevated liver enzymes, low platelet count syndrome, IUGR: Intrauterine growth retardation, PG: Plasma glucose 


\begin{tabular}{|c|c|c|c|c|c|c|c|c|c|c|c|c|c|c|}
\hline \multirow{2}{*}{$\begin{array}{l}\text { Length of } \\
\text { ICU stay }\end{array}$} & \multicolumn{2}{|c|}{ HELLP } & \multicolumn{2}{|c|}{ Eclampsia } & \multicolumn{2}{|c|}{ Renal failure } & \multicolumn{2}{|c|}{ Ablatio placenta } & \multicolumn{2}{|c|}{ DIC } & \multicolumn{2}{|c|}{ IUGR } & \multicolumn{2}{|c|}{ Perinatal mortality } \\
\hline & + & - & + & - & + & - & + & - & + & - & + & - & + & - \\
\hline \multicolumn{15}{|l|}{$\leq 2$} \\
\hline$n$ & 9 & 38 & 3 & 44 & 0 & 47 & 3 & 44 & 2 & 45 & 38 & 9 & 12 & 35 \\
\hline Percentage & 47.4 & 86.4 & 60.0 & 75.9 & 0.0 & 77.0 & 75.0 & 74.6 & 40.0 & 77.6 & 79.2 & 60.0 & 66.7 & 77.8 \\
\hline \multicolumn{15}{|l|}{$>2$} \\
\hline$n$ & 10 & 6 & 2 & 14 & 2 & 14 & 1 & 15 & 3 & 13 & 10 & 6 & 6 & 10 \\
\hline Percentage & 52.6 & 13.6 & 40.0 & 24.1 & 100 & 23.0 & 25.0 & 25.4 & 60.0 & 22.4 & 20.8 & 40.0 & 33.3 & 22.2 \\
\hline Total $^{\#}$ & 19 & 44 & 5 & 58 & 2 & 61 & 4 & 59 & 5 & 58 & 48 & 15 & 18 & 45 \\
\hline$P$ & \multicolumn{2}{|c|}{$0.001^{*}$} & \multicolumn{2}{|c|}{$0.59 * *$} & \multicolumn{2}{|c|}{$0.06^{* *}$} & \multicolumn{2}{|c|}{$0.01 * *$} & \multicolumn{2}{|c|}{$0.09 * *$} & \multicolumn{2}{|c|}{$0.13^{*}$} & \multicolumn{2}{|c|}{$0.36^{*}$} \\
\hline
\end{tabular}

*Pearson $\chi^{2}$; **Fisher's exact test. DIC: Disseminated intravascular coagulation, HELLP: Hemolysis, elevated liver enzymes, low platelet count syndrome, ICU: Intensive care unit, IUGR: Intrauterine growth restriction

\section{Table 6: Comparison of length of stay at intensive care} unit and birth weight by degree of glycemia

\begin{tabular}{lccccc}
\hline PG & \multicolumn{2}{c}{ ICU day } & & \multicolumn{2}{c}{ Newborn weight } \\
\cline { 2 - 3 } \cline { 5 - 6 } & $>\mathbf{2}$ & $\mathbf{5 2}$ & & $\mathbf{1 8 0 0}$ & $<\mathbf{1 8 0 0}$ \\
\hline$\leq 92$ & 9 & 25 & & 17 & 17 \\
$n$ & 56.2 & 53.2 & & 70.9 & 43.6 \\
$\quad$ Percentage & 7 & 22 & & 7 & 22 \\
$>92$ & 43.8 & 46.8 & & 29.2 & 56.4 \\
$n$ & 16 & 47 & & 24 & 39 \\
$\quad$ Percentage & \multicolumn{3}{c}{$0.83 *$} \\
Total & \multicolumn{3}{c}{$0.035 *$} \\
$P$ & *Pearson $\chi^{2}$. PG: Plasma glucose, ICU: Intensive care unit
\end{tabular}

hyperglycemia have a significantly lower mortality than those with normal blood glucose levels. ${ }^{[27]}$

The stress response is mediated by the hypothalamic-pituitaryadrenal axis. ${ }^{[28]}$ This stimulus leads to activation of adrenal glands through sympathetic ganglions, thereby release of catecholamines, ${ }^{[29]}$ which together with cortisol, glucagon, and growth hormon stimulate hepatic gluconeogenesis and glycogenolysis. ${ }^{[30]}$ This process further contributes hyperglycemia through activated hepatic gluconeogenesis, also together with pro-inflammatory cytokines such as tumor necrosis factor- $\alpha$, interleukin (IL)-1 and IL- $6^{[31]}$ and adipokines ${ }^{[32]}$ released from adipocytes, inhibits glucose uptake in peripheral tissues, ${ }^{[31]}$ eventually leading to peripheral insulin resistance.

In the light of all these scientific but contradictory information, we decided to investigate, for the first time to our knowledge, the possible relationship between the admission PG levels with maternal and fetal complications among a group of pregnant women with severe preeclampsia who were being treated at the ICU.

In this study, we demonstrated that elevated admission PG $(>92 \mathrm{mg} / \mathrm{dL}$ ) is encountered in $46 \%$ of our study population and is significantly associated with several complications related to preeclampsia, such as HELLP syndrome, eclampsia, and DIC defect.
PG levels were significantly and positively correlated with neutrophil count, NLR, ALT, and AST levels, also but inversely, with platelet count. Clinically, there was a significant correlation between PG and the overall length of stay at the ICU and at the hospital.

As defined in the material and methods section, women with admission HbA1c levels above 5.7 were excluded, to rule out prediabetes and diabetes mellitus. Mean $\mathrm{HbA1c}$ levels were indifferent between women with high and normal admission PG levels (4.71 vs. 4.70) and also between women who stayed at the ICU more than 2 days and 2 days or less (4.58 vs. 4.75). In the present study, mean $\mathrm{HbA} 1 \mathrm{c}$ levels were significantly lower only in women who delivered babies less than $1800 \mathrm{~g}$ when compared with the ones who delivered heavier babies (4.60 vs. $4.89, P=0.003)$. Overall, HbA1c values showed significant correlation positively with platelet count and birth weight and negatively with $\mathrm{Hb}$ and hematocrit values. Based on our data, we confirmed that $\mathrm{HbAlc}$ levels were minimally affected by stress, at least in pregnancy complications such as severe preeclampsia.

Platelet count was found to be one of the prognostic markers in this study. Mean platelet count was significantly lower among women with high admission PG level and who were kept in ICU longer than 2 days, in comparison to those with normal PG level and who were kept in ICU for 2 days or less (156,319 vs. 192,558 and 121,687 vs. 194,319 , respectively). Mean platelet values were conversely correlated with $\mathrm{HbAlc}$ and inversely correlated with PG, $\mathrm{Hb}$, hematocrit, and diastolic blood pressure. In regard to ICU stay, the laboratory parameters which showed significant and direct correlation were PG, neutrophil, NLR, LDH, AST, and ALT values.

Neutrophils are the most abundant leukocytes in human circulation, also the first ones recruited to the inflammatory site to eliminate the pathogens. Hyperactivated neutrophils, in situations like burn shock or traumatic injury, contribute to oxidative tissue damage and eventual organ failure. ${ }^{[3,34]}$ Hyperglycemia induces neutrophil dysfunction proportionally with its extent ${ }^{[35]}$ through myeloperoxidase biochemical 
Table 7: Comparison of perinatal complications among pregnant women with preeclampsia by elevated glucose and glycosylated hemoglobin status

\begin{tabular}{|c|c|c|c|c|c|c|c|c|}
\hline & \multicolumn{2}{|c|}{ HELLP } & \multicolumn{2}{|c|}{ Eclampsia } & \multicolumn{2}{|c|}{ Renal failure } & \multicolumn{2}{|c|}{ Ablatio placenta } \\
\hline & $n$ & Mean \pm SD & $n$ & Mean \pm SD & $n$ & Mean \pm SD & $n$ & Mean \pm SD \\
\hline \multicolumn{9}{|l|}{ PG } \\
\hline+ & 19 & $116.52 \pm 40.13$ & 5 & $166.00 \pm 46.95$ & 2 & $186.00 \pm 57.98$ & 4 & $96.50 \pm 21.82$ \\
\hline- & 44 & $94.13 \pm 22.68$ & 58 & $95.27 \pm 21.32$ & 61 & $98.09 \pm 25.64$ & 59 & $101.18 \pm 31.14$ \\
\hline$P$ & \multicolumn{2}{|c|}{0.007} & \multicolumn{2}{|r|}{0.027} & \multicolumn{2}{|r|}{0.001} & \multicolumn{2}{|r|}{0.76} \\
\hline \multicolumn{9}{|c|}{$\mathrm{HbA1c}$} \\
\hline+ & 19 & $4.67 \pm 0.36$ & 5 & $4.86 \pm 0.18$ & 2 & $4.50 \pm 0.84$ & 4 & $4.65 \pm 0.63$ \\
\hline- & 44 & $4.73 \pm 0.38$ & 58 & $4.70 \pm 0.38$ & 61 & $4.72 \pm 0.36$ & 59 & $4.71 \pm 0.36$ \\
\hline$P$ & \multicolumn{2}{|c|}{0.606} & \multicolumn{2}{|r|}{0.372} & \multicolumn{2}{|r|}{0.421} & \multicolumn{2}{|r|}{0.75} \\
\hline
\end{tabular}

PG: Plasma glucose, HbA1c: Glycosylated hemoglobin, SD: Standard deviation, HELLP: Hemolysis, Elevated liver enzymes, low platelet count syndrome, PG+: Admission glucose level is high, PG-: Admission glucose level is normal

Table 8: Comparison of perinatal complications among pregnant women with preeclampsia by elevated glucose and glycosylated hemoglobin status

\begin{tabular}{|c|c|c|c|c|c|c|}
\hline & \multicolumn{2}{|r|}{ DIC } & \multicolumn{2}{|r|}{ IUGR } & \multicolumn{2}{|c|}{ Perinatal mortality } \\
\hline & $n$ & Mean \pm SD & $n$ & Mean \pm SD & $n$ & Mean \pm SD \\
\hline \multicolumn{7}{|l|}{ PG } \\
\hline+ & 5 & $130.60 \pm 57.48$ & 48 & $103.12 \pm 31.66$ & 18 & $103.72 \pm 27.85$ \\
\hline- & 58 & $98.32 \pm 26.41$ & 15 & $93.73 \pm 26.25$ & 45 & $99.75 \pm 31.76$ \\
\hline$P$ & & 0.279 & & 0.302 & & 0.645 \\
\hline \multicolumn{7}{|c|}{$\mathrm{HbA} 1 \mathrm{c}$} \\
\hline+ & 5 & $4.74 \pm 0.33$ & 48 & $4.72 \pm 0.38$ & 18 & $4.57 \pm 0.41$ \\
\hline- & 58 & $4.71 \pm 0.38$ & 15 & $4.68 \pm 0.35$ & 45 & $4.77 \pm 0.35$ \\
\hline$P$ & & 0.87 & & 0.754 & & 0.060 \\
\hline
\end{tabular}

PG: Plasma glucose, DIC: Disseminated intravascular coagulation, IUGR: Intrauterine growth restriction, SD: Standard deviation, $\mathrm{HbAlc:}$ Glycosylated hemoglobin, $\mathrm{PG}+$ : Admission glucose level is high, PG-: Admission glucose level is normal

Table 9: Comparison of glucose and glycosylated hemoglobin values among pregnant women with preeclampsia by the birth weight status

\begin{tabular}{llcllc}
\hline Birth & \multicolumn{2}{c}{ PG } & & \multicolumn{2}{c}{ HbA1c } \\
\cline { 2 - 3 } \cline { 5 - 6 } weight $(\mathbf{g})$ & $\boldsymbol{n}$ & Mean \pm SD & & $\boldsymbol{n}$ & Mean \pm SD \\
\hline$\geq 1800$ & 24 & $95.33 \pm 30.71$ & & 24 & $4.89 \pm 0.30$ \\
$<1800$ & 39 & $104.30 \pm 30.29$ & & 39 & $4.60 \pm 0.37$ \\
$P$ & & 0.260 & & 0.003 \\
\hline$P$
\end{tabular}

PG: Plasma glucose, SD: Standard deviation, HbA1c: Glycosylated hemoglobin

Table 10: Correlation of glycosylated hemoglobin values with other laboratory characteristics and birth weight

\begin{tabular}{lcccc}
\hline HbA1c & Platelet & Hb & Hematocrit & Birth weight \\
\hline$r$ & $0.251^{*}$ & $-0.278^{*}$ & $-0.268^{*}$ & $0.307^{*}$ \\
$P$ & 0.047 & 0.027 & 0.034 & 0.015 \\
\hline *Pearson. HbA1c: Glycosylated hemoglobin
\end{tabular}

pathway, reduces neutrophil degranulation, and exaggerates coagulation in healthy controls who were exposed to glucose infusion and endotoxin. ${ }^{[36]}$
Lately, neutrophil biology is being investigated as potential biomarkers by which to predict the outcome of critically ill, hospitalized patients. Accordingly, the blood NLR has been identified as a potentially useful marker of clinical outcome in disease states with an inflammatory component. Its association with a poor outcome in patients with cardiovascular diseases, malignancies, cystic fibrosis, and familial mediterranean fever, ${ }^{[37,38]}$ and also in patients with obstetric complications such as preeclampsia, preterm delivery, miscarriage, and intrahepatic cholestasis ${ }^{[39-43]}$ have been reported previously. In the present study, both neutrophil count and NLR were elevated in women with PG above $92 \mathrm{mg} / \mathrm{dL}$ in comparison to those with normal PG levels ( 10.81 vs. $8.85 / \mu \mathrm{L}$ and 6.07 vs. 4.55 , respectively). Likewise, women who stayed at ICU more than 2 days revealed higher NLR, when compared with those who stayed shorter (11.25 vs. $9.24 / \mu \mathrm{L}$ and 6.95 vs. 4.67 , respectively). NLR was found to be positively correlated with admission PG $(P=0.026)$, duration of stay at ICU $(P=0.015)$, and at the hospital $(P=0.031)$. Finally, admission $\mathrm{PG}$, platelet count, fibrinogen, AST, and ALT values were still significantly associated with the length of stay at ICU.

\section{Conclusion}

It has been debated whether increased glucose is a direct mediator of adverse outcomes or just a marker of severe disease conditions. Since hyperglycemia improved immediately following delivery, we claim that hyperglycemia is an acute reaction, a reflection of disease severity rather than the consequence of a preexisting metabolic disorder.

We confirmed that admission PG was a significant and independent marker. The simple and inexpensive characteristic of the test, also availability of results soon after admission, provides important prognostic information and permits early risk stratification and decision-making in clinical management of women with severe preeclampsia. Therefore, we suggest PG levels to be added to the routine high-risk pregnancy panel on initial presentation to the hospital. In selecting pregnant 
Table 11: Correlation of neutrophil lymphocyte ratio with other laboratory characteristics and length of hospital/ intensive care unit stay

\begin{tabular}{lccccc}
\hline N/L ratio & PG & $\mathbf{N}$ & $\mathbf{L}$ & ICU day & Hospital day \\
\hline$r$ & $0.280^{* *}$ & $0.727^{*}$ & $-0.565^{*}$ & $0.305^{* *}$ & $0.272^{* *}$ \\
$P$ & 0.026 & 0.000 & 0.000 & 0.015 & 0.031 \\
\hline *Pearson, **Spearman's. N/L ratio: & Neutrophilymphocyte
\end{tabular}

ICU: Intensive care unit, PG: Plasma glucose

Table 12: Correlation of length of hospital/intensive care unit stay with other laboratory characteristics

\begin{tabular}{lcccccc}
\hline ICU day & PG & $\boldsymbol{n}$ & N/L ratio & LDH & AST & ALT \\
\hline$r$ & $0.506^{*}$ & $0.327^{*}$ & $0.305^{* *}$ & $201.0^{\mathrm{u}}$ & $221.0^{\mathrm{u}}$ & $210.0^{\mathrm{u}}$ \\
$P$ & 0.000 & 0.009 & 0.015 & 0.006 & 0.014 & 0.009 \\
\hline
\end{tabular}

*Pearson, **Spearman's, "Mann-Whitney U-Test. ALT: Alanine aminotransferase, AST: Aspartate aminotransferase, LDH: Lactate dehydrogenase, N/L ratio: Neutrophil/lymphocyte ratio, ICU: Intensive care unit, PG: Plasma glucose

\begin{tabular}{|c|c|c|c|c|c|}
\hline Platelet & $P G$ & Hb A1c & $\mathrm{Hb}$ & Hematocrit & Diastolic BP \\
\hline$r$ & $-0.360^{*}$ & $0.251^{*}$ & $-0.427 *$ & $-0.361 *$ & $-0.317^{*}$ \\
\hline$P$ & 0.004 & 0.047 & 0.000 & 0.004 & 0.011 \\
\hline
\end{tabular}

*Pearson. BP: Blood pressure, PG: Plasma glucose, Hb A1c:

Glycosylated hemoglobin

women to be managed at the ICU, admission PG cutoff level of $92 \mathrm{mg} / \mathrm{dL}$ can be used. HbAlc measurement, on the other hand, was not demonstrated to be a determinant of acute hyperglycemia. Although NLR was significantly correlated with PG, it was not found to be an independent parameter. For that reason, we suggest that in addition of this laboratory test as a marker it would not contribute to the clinical management.

There are potential limitations in this study that should be acknowledged. First, our study population was considerably small, especially when women with particular complications associated with preeclampsia are considered. Furthermore, there is no direct evidence supporting the relationship between acute hyperglycaemia and stress. As we did not measure stress response hormones or insulin resistance through insulin and glucose measurements, it was not possible for us to specifically identify which mechanism might be more responsible for the hyperglycemia. Further large, prospective, comparative studies are urgently needed.

\section{Financial support and sponsorship}

Nil.

\section{Conflicts of interest}

There are no conflicts of interest.

\section{RefEREnCes}

1. McCowen KC, Malhotra A, Bistrian BR. Stress-induced hyperglycemia.
Crit Care Clin 2001;17:107-24.

2. Langouche L, Van den Berghe G. The dynamic neuroendocrine response to critical illness. Endocrinol Metab Clin North Am 2006;35:777-91, ix.

3. Badawi O, Waite MD, Fuhrman SA, Zuckerman IH. Association between intensive care unit-acquired dysglycemia and in-hospital mortality. Crit Care Med 2012;40:3180-8.

4. Kosiborod M, Rathore SS, Inzucchi SE, Masoudi FA, Wang Y, Havranek EP, et al. Admission glucose and mortality in elderly patients hospitalized with acute myocardial infarction: Implications for patients with and without recognized diabetes. Circulation 2005;111:3078-86.

5. Capes SE, Hunt D, Malmberg K, Gerstein HC. Stress hyperglycaemia and increased risk of death after myocardial infarction in patients with and without diabetes: A systematic overview. Lancet 2000;355:773-8.

6. Deedwania P, Kosiborod M, Barrett E, Ceriello A, Isley W, Mazzone T, et al. Hyperglycemia and acute coronary syndrome: A scientific statement from the American Heart Association diabetes committee of the council on nutrition, physical activity, and metabolism. Circulation 2008; 117:1610-9.

7. Capes SE, Hunt D, Malmberg K, Pathak P, Gerstein HC. Stress hyperglycemia and prognosis of stroke in nondiabetic and diabetic patients: A systematic overview. Stroke 2001;32:2426-32.

8. Bruno A, Levine SR, Frankel MR, Brott TG, Lin Y, Tilley BC, et al. Admission glucose level and clinical outcomes in the NINDS rt-PA stroke trial. Neurology 2002;59:669-74.

9. Sung J, Bochicchio GV, Joshi M, Bochicchio K, Tracy K, Scalea TM. Admission hyperglycemia is predictive of outcome in critically ill trauma patients. J Trauma 2005;59:80-3.

10. Svensson AM, McGuire DK, Abrahamsson P, Dellborg M. Association between hyper- and hypoglycaemia and 2 year all-cause mortality risk in diabetic patients with acute coronary events. Eur Heart J 2005;26:1255-61.

11. Pinto DS, Skolnick AH, Kirtane AJ, Murphy SA, Barron HV, Giugliano RP, et al. U-shaped relationship of blood glucose with adverse outcomes among patients with ST-segment elevation myocardial infarction. J Am Coll Cardiol 2005;46:178-80.

12. HAPO Study Cooperative Research Group, Metzger BE, Lowe LP, Dyer AR, Trimble ER, Chaovarindr U, et al. Hyperglycemia and adverse pregnancy outcomes. N Engl J Med 2008;358:1991-2002.

13. American Diabetes Association. Diagnosis and classification of diabetes mellitus. Diabetes Care 2013;36 Suppl 1:S67-74.

14. Coustan DR, Lowe LP, Metzger BE, Dyer AR. International Association of Diabetes and Pregnancy Study Groups. The hyperglycemia and adverse pregnancy outcome (HAPO) study: Paving the way for new diagnostic criteria for gestational diabetes mellitus. Am J Obstet Gynecol 2010;202:654.e1-6.

15. International Association of Diabetes and Pregnancy Study Groups Consensus Panel, Metzger BE, Gabbe SG, Persson B, Buchanan TA, Catalano PA, et al. International association of diabetes and pregnancy study groups recommendations on the diagnosis and classification of hyperglycemia in pregnancy. Diabetes Care 2010;33:676-82.

16. American Diabetes Association. Standards of medical care in diabetes-2014. Diabetes Care 2014;37 Suppl 1:S14-80.

17. Steegers EA, von Dadelszen P, Duvekot JJ, Pijnenborg R. Pre-eclampsia. Lancet 2010;376:631-44.

18. American College of Obstetricians and Gynecologists Task Force on Hypertension in Pregnancy. Hypertension in Pregnancy; 2013. Available from: http://www.acog.org/resourcesandpublications/ taskforceandworkgroupreports/hypertensioninpregnancy. [Last accessed on 2019 May 30].

19. Publications Committee, Society for Maternal-Fetal Medicine, Sibai BM. Evaluation and management of severe preeclampsia before 34 weeks' gestation. Am J Obstet Gynecol 2011;205:191-8.

20. Roberts JM, Edep ME, Goldfien A, Taylor RN. Sera from preeclamptic women specifically activate human umbilical vein endothelial cells in vitro: Morphological and biochemical evidence. Am J Reprod Immunol 1992;27:101-8.

21. Gervasi MT, Chaiworapongsa T, Pacora P, Naccasha N, Yoon BH, Maymon E, et al. Phenotypic and metabolic characteristics of monocytes and granulocytes in preeclampsia. Am J Obstet Gynecol 2001;185:792-7. 
22. Kenny LC, Baker PN, Cunningham FG, editors. Chesley's Hypertensive Disorders in Pregnancy. Epidemiology of the hypertensive disorders of pregnancy: $3^{\text {rd }}$ edition. Amsterdam, The Netherlands: Elsevier. p. 335-51.

23. Lindheimer MD, Roberts JM, Cunningham GC, Chesley L. Classification of the Hypertensive Disorders in Pregnancy. In: Lindheimer MD, Roberts JM, Cunningham GC, editors. Chesley's Hypertensive Disorders in Pregnancy. $3^{\text {rd }}$ edition. Amsterdam, The Netherlands: Elsevier; 2009. p. 1-24.

24. Ali S, Dornhorst A. Diabetes in pregnancy: Health risks and management. Postgrad Med J 2011;87:417-27.

25. Yogev Y, Chen R, Hod M, Coustan DR, Oats JJ, McIntyre HD, et al. Hyperglycemia and adverse pregnancy outcome (HAPO) study: Preeclampsia. Am J Obstet Gynecol 2010;202:255.e1-7.

26. Soeters MR, Soeters PB. The evolutionary benefit of insulin resistance. Clin Nutr 2012;31:1002-7.

27. Tiruvoipati R, Chiezey B, Lewis D, Ong K, Villanueva E, Haji K, et al. Stress hyperglycemia may not be harmful in critically ill patients with sepsis. J Crit Care 2012;27:153-8.

28. Vermes I, Beishuizen A. The hypothalamic-pituitary-adrenal response to critical illness. Best Pract Res Clin Endocrinol Metab 2001;15:495-511.

29. Clark L, Preissig C, Rigby MR, Bowyer F. Endocrine issues in the pediatric intensive care unit. Pediatr Clin North Am 2008;55:805-33, xiii.

30. Chernow B, Rainey TG, Lake CR. Endogenous and exogenous catecholamines in critical care medicine. Crit Care Med 1982;10:409-16.

31. Dungan KM, Braithwaite SS, Preiser JC. Stress hyperglycaemia. Lancet 2009;373:1798-807.

32. Jernås $\mathrm{M}$, Olsson B, Sjöholm K, Sjögren A, Rudemo M, Nellgård B, et al. Changes in adipose tissue gene expression and plasma levels of adipokines and acute-phase proteins in patients with critical illness. Metabolism 2009;58:102-8.

33. Hazeldine J, Hampson P, Lord JM. The impact of trauma on neutrophil function. Injury 2014;45:1824-33.

34. Noel G, Wang Q, Schwemberger S, Hanson C, Giacalone N, Haar L, et al. Neutrophils, not monocyte/macrophages, are the major splenic source of postburn IL-10. Shock 2011;36:149-55.

35. McManus LM, Bloodworth RC, Prihoda TJ, Blodgett JL, Pinckard RN. Agonist-dependent failure of neutrophil function in diabetes correlates with extent of hyperglycemia. J Leukoc Biol 2001;70:395-404.

36. Stegenga ME, van der Crabben SN, Blümer RM, Levi M, Meijers JC, Serlie MJ, et al. Hyperglycemia enhances coagulation and reduces neutrophil degranulation, whereas hyperinsulinemia inhibits fibrinolysis during human endotoxemia. Blood 2008;112:82-9.

37. Núñez J, Núñez E, Bodí V, Sanchis J, Miñana G, Mainar L, et al. Usefulness of the neutrophil to lymphocyte ratio in predicting long-term mortality in ST segment elevation myocardial infarction. Am J Cardiol 2008; 101:747-52.

38. Balta S, Demirkol S, Celik T, Kucuk U, Unlu M, Arslan Z, et al. Association between coronary artery ectasia and neutrophil-lymphocyte ratio. Angiology 2013;64:627-32.

39. Kirbas A, Biberoglu E, Daglar K, İskender C, Erkaya S, Dede H, et al. Neutrophil-to-lymphocyte ratio as a diagnostic marker of intrahepatic cholestasis of pregnancy. Eur J Obstet Gynecol Reprod Biol 2014;180:12-5.

40. Borzychowski AM, Sargent IL, Redman CW. Inflammation and pre-eclampsia. Semin Fetal Neonatal Med 2006;11:309-16.

41. Sacks GP, Studena K, Sargent K, Redman CW. Normal pregnancy and preeclampsia both produce inflammatory changes in peripheral blood leukocytes akin to those of sepsis. Am J Obstet Gynecol 1998;179:80-6.

42. Christiansen OB, Nielsen HS, Kolte AM. Inflammation and miscarriage. Semin Fetal Neonatal Med 2006;11:302-8.

43. Romero R, Espinoza J, Gonçalves LF, Kusanovic JP, Friel LA, Nien JK Inflammation in preterm and term labour and delivery. Semin Fetal Neonatal Med 2006;11:317-26. 